\title{
Recolonization of sediment-associated microalgae and effects of estuarine infauna on microalgal production
}

\author{
Michael W. Davis ${ }^{1 *}$ and Henry Lee, $\mathrm{II}^{2}$ \\ ${ }^{1}$ Department of Botany and Plant Pathology, Oregon State University, Marine Science Center, Newport, Oregon 97365, USA \\ ${ }^{2}$ US Environmental Protection Agency, Corvallis Environment Research Laboratory, Marine Division, \\ Marine Science Center, Newport, Oregon 97365, USA
}

\begin{abstract}
Experiments were performed to determine the rate of recolonization of sediment-associated microalgae and effects of infauna on microalgal biomass and production. Estuarine sediment was defaunated and transplanted to the field and the laboratory. Recolonization of sediment by flora and fauna, relative to control sediment, was measured by chlorophyll $a$, gross primary production, community $\mathrm{O}_{2}$ uptake and infaunal abundance, sampled at Days 1, 10, and 40. Microalgal colonization in the field was, rapid, with chlorophyll a returning to control levels by Day 10 . Infaunal density returned to control levels within $40 \mathrm{~d}$. In the field experiment, the effects of the infauna on the microalgae may have been confounded both by the rapid rate of infaunal recolonization and by the import of microalgae. The laboratory experiment reduced these problems. Removal of infauna in the laboratory, primarily tanaids, increased sediment-associated microalgal growth. After $40 \mathrm{~d}$, chlorophyll $a$ was 4 times greater and gross primary production 2 times greater in the defaunated sediment than in the controls. Grazing of microalgae by infauna appeared to be the mechanism of control. Patterns of community $\mathrm{O}_{2}$ uptake were difficult to interpret and showed no simple relationship with infaunal density. These experiments indicate that estuarine infauna is one of the factors controlling sedimentassociated microalgal biomass and production.
\end{abstract}

\section{INTRODUCTION}

Estuarine sand and mud habitats harbor diverse assemblages of pennate diatoms, blue-green algae and flagellates (Fenchel, 1969). These microalgae can be highly productive (Pomeroy, 1959; Cadée and Hegeman, 1974). Physical factors such as light, temperature, and sediment type play an important role in regulating the distribution and abundance of sediment-associated microalgae (Pomeroy, 1959; Cadée and Hegeman, 1974). However, nutrients probably are not limiting (Admiraal, 1977) due to the relatively high concentrations in estuaries and the release of nutrients from sediments (Montgomery et al., 1979; Welsh, 1980).

Importance of biotic factors in regulating sedimentassociated microalgae is poorly understood. Many epifaunal and infaunal deposit feeders ingest and assimi-

\footnotetext{
- Present address: Harbor Branch Institution, R.R.1, Box 196-A, Ft. Pierce, Florida 33450, USA
}

late microalgae (Sanders et al., 1962; Levinton, 1980). Experimental manipulations of the estuarine gastropods Hydrobia spp. (Fenchel and Kofoed, 1976), Nassarius obsoletus (Say) (Pace et al., 1979), and Bembicium auratum (Quoy and Gainard) (Branch and Branch, 1980) demonstrated that epifaunal deposit feeders can regulate microalgal biomass. The freshwater epibenthic amphipod Hyallela azteca (Sauggure) either stimulated or depressed microalgal production depending on amphipod density (Hargrave, 1970). Experimental studies of infaunal regulation of microalgae include the investigation by White et al. (1980), who found that the sand dollar Mellita quinquiesperforata (Leske) had no significant effect on chlorophyll a concentrations in sediment, and the study by Coles (1979), who gave qualitative evidence for infaunal regulation of microalgae.

In previous experiments we observed that defaunated sediment developed a golden-brown 'diatom' layer within a few days ( $\mathrm{H}$. Lee, and J. Lee unpubl.). 
This suggested the hypotheses that microalgal colonization was rapid and that infauna regulated microalgal populations. To test these hypotheses, we examined microalgal colonization of defaunated sediment in the field and laboratory. Here we present the results of these experiments and discuss the role of infauna in controlling sediment-associated microalgae.

\section{MATERIALS AND METHODS}

\section{Study site}

Experiments were performed on an intertidal sand flat in Yaquina Bay, Oregon, USA $\left(44^{\circ} 35^{\prime} \mathrm{N} ; 124^{\circ} 04^{\prime} \mathrm{W}\right)$ adjacent to the Oregon State University Marine Science Center, Newport, and in a laboratory at the Marine Science Center. The field study site was 1.0 to $1.1 \mathrm{~m}$ above Mean Lower Low Water (MLLW) and was exposed twice daily for an average exposure of $6 \mathrm{~h} \mathrm{~d}^{-1}$. Maximum tidal amplitude in Yaquina Bay is $3 \mathrm{~m}$. Salinity ranged from 28 to $30 \% \mathrm{~S}$; water temperature, from 12 to $14{ }^{\circ} \mathrm{C}$ during summer. Sediment mean grain size was 2.64 phi $(160 \mu \mathrm{m})$, a well-sorted, fine sand. The microalgal community was composed primarily of a diverse assemblage of pennate diatoms (Amspoker and McIntire, 1978). During summer, the macroalgae Enteromorpha prolifera (Mull.) J. Ag. and Ulva expansa (Setch.) S. \& G. covered a large portion of the study site. Seasonal rates of gross primary production by sediment-associated microalgae ranged from 20 to $150 \mathrm{mg} \mathrm{C} \mathrm{m}^{-2} \mathrm{~h}^{-1}$ (Davis, 1981).

\section{Experimental design}

The effect of infauna on microalgae was evaluated by comparing microalgal biomass and production of an undisturbed sediment community with that of defaunated sediment. Defaunated sediment was prepared by collecting sediment at the field site, sieving it through a 1-mm mesh screen, and then freezing it for approximately $1 \mathrm{mo}$. In the field experiment, defaunated sediment was placed in cylinders of fiberglass screening (1.5-mm mesh). These cylinders had a surface area of $411.9 \mathrm{~cm}$ at the open end, were $10 \mathrm{~cm}$ deep, and were completely embedded within the sediment. Eight defaunated sediment cylinders and 8 control plots (unmanipulated sediment) were randomly assigned to $57 \mathrm{~cm} \times 57 \mathrm{~cm}$ plots within a $285 \mathrm{~cm} \times 228 \mathrm{~cm}$ block. The experiment was initiated in June 1980. Macroalgae were periodically removed from the study site. Defaunated and control treatments were sampled 1, 10, and $40 \mathrm{~d}$ after transplanting the defaunated sediment into the field. At each sampling date, 2 defaunated cylinders and 2 control plots were sampled. Three cores $\left(45.6 \mathrm{~cm}^{2}, 4 \mathrm{~cm}\right.$ deep) were taken within each defaunated cylinder or control plot. These cores were brought into the laboratory and used to assess metabolic activity, chlorophyll a concentration, and macrofaunal abundance.

In the laboratory experiment, cores $\left(36.3 \mathrm{~cm}^{2}, 4 \mathrm{~cm}\right.$ deep) were either taken in the field or filled with defaunated sediment and then maintained in flowing seawater. Microalgae growing in defaunated sediment came from an initial innoculum of suspended microalgae originating from immersion of the control sediment into the water bath and by surviving microalgae. The seawater was sand-filtered, UV-treated, and maintained at $11.0 \pm 1.0^{\circ} \mathrm{C}$ and at a salinity of $30 \%$ S. Light was supplied by cool-white fluorescent and incandescent sources at $150 \mu \mathrm{E} \mathrm{m}^{-2} \mathrm{~s}^{-1}$ photosynthetically active radiation with a 12-h light and 12-h dark photoperiod. Light was measured with a Licor ${ }^{\circledR}$ quantum meter and salinity with an AO Goldberg ${ }^{\circledR}$ temperature-compensated refractometer. Metabolic activity, chlorophyll a concentration and macrofaunal abundance were determined 1,10 , and $40 \mathrm{~d}$ after initiation of the experiment. Three cores of both treatments were sampled on each of the 3 dates. The laboratory experiment was initiated in January 1981. To determine the effects of maintaining cores of the natural community in the laboratory, metabolic activity, chlorophyll a concentration, and animal abundance were measured in 3 cores taken from the field $1 \mathrm{~d}$ before termination of the experiment (i.e. day 39) and compared to the control cores held for $40 \mathrm{~d}$.

\section{Metabolic activity}

Gross primary production and community $\mathrm{O}_{2}$ uptake were measured in the laboratory using changes of oxygen in stirred, light and dark chambers designed to hold intact cores of sediment (Davis, 1981). In the field experiment, the 3 cores from a defaunated or control plot were incubated in 6.0-1 Plexiglas chambers. In the laboratory experiment, a 300-ml Plexiglas chamber was used which allowed an independent measurement for each core. The large chamber required $1 \mathrm{~h}$ dark and $1 \mathrm{~h}$ light incubation for measurements of community $\mathrm{O}_{2}$ uptake and net community $\mathrm{O}_{2}$ production, respectively. Incubations were performed at 13 to $14{ }^{\circ} \mathrm{C}$, a light intensity of $210 \mu \mathrm{E} \mathrm{m}^{-2} \mathrm{~s}^{-1}$ and $30 \% \mathrm{~S}$. The small chamber required $0.5 \mathrm{~h}$ for each measurement. Oxygen was measured polarographically using an Orbisphere ${ }^{\star x}$ salinity-compensated $\mathrm{O}_{2}$ system. Gross primary production was calculated by addition of community $\mathrm{O}_{2}$ uptake to net community $\mathrm{O}_{2}$ production. Calculated rates of gross primary production in $\mathrm{mg} \mathrm{O}_{2} \mathrm{~m}^{-2} \mathrm{~h}^{-1}$ were 
converted to $\mathrm{mg} \mathrm{C} \mathrm{m} \mathrm{m}^{-2} \mathrm{~h}^{-1}$ assuming a photosynthetic quotient of 1.2 and community $\mathrm{O}_{2}$ uptake rates in $\mathrm{mg}$ $\mathrm{O}_{2} \mathrm{~m}^{-2} \mathrm{~h}^{-1}$ were converted to $\mathrm{mg} \mathrm{C} \mathrm{m} \mathrm{C}^{-2} \mathrm{~h}^{-1}$ assuming respiratory quotient of 1.0 (Westlake, 1965).

\section{Chlorophyll $a$ analysis}

After metabolic measurements, a core $\left(4.15 \mathrm{~cm}^{2}\right.$, $3 \mathrm{~cm}$ deep) for chlorophyll a analysis was taken from each larger core. These small cores were frozen intact and the top $1 \mathrm{~cm}$ was sectioned off and then extracted in $90 \%$ acetone. Chlorophyll a concentration was measured using the method of Strickland and Parsons (1972). The Lorenzen equation was used to calculate $\mathrm{mg}$ chlorophyll $a \mathrm{~m}^{-2}$, corrected for pheopigments. These values are not corrected for chlorophyllide, but are suitable for comparing the effect of grazing on adjacent plots (Pace et al., 1979; Whitney and Darley, 1979).

\section{Macrofaunal abundance}

After removing the subcores for chlorophyll $a$ analysis, the remaining sediment in the 3 field cores $\left(\Sigma 124.35 \mathrm{~cm}^{2}\right)$ or each laboratory core $\left(32.15 \mathrm{~cm}^{2}\right)$ was

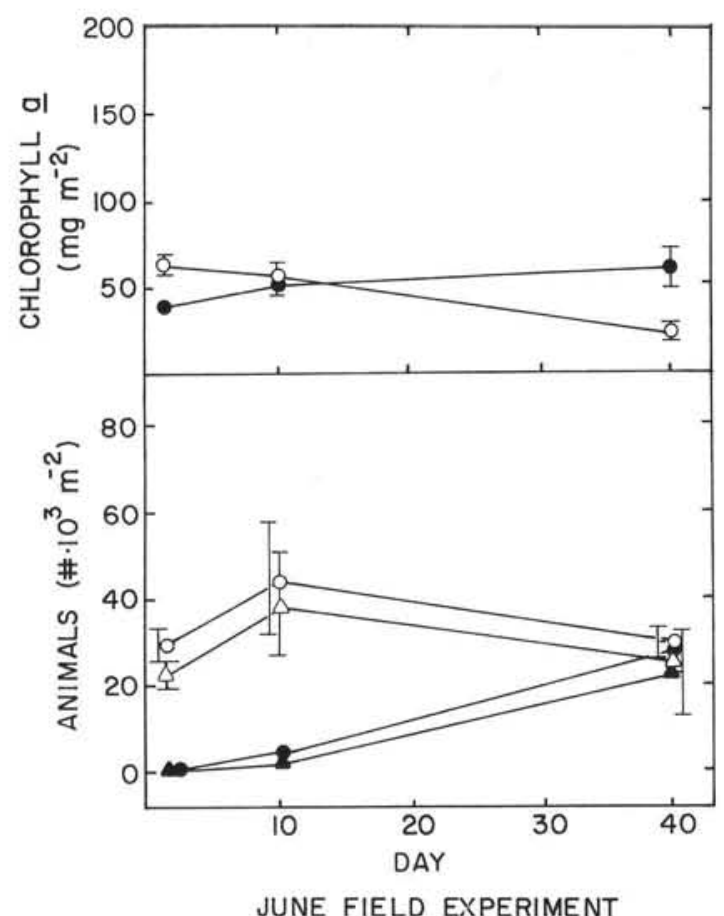

Fig. 1. Results of field defaunation experiment sampled at Days 1, 10 and 40, showing concentration of chlorophyll $a$ in control $(O)$ and defaunated $(\bullet)$ sediment, total infaunal density in control $(0)$ and defaunated $(\bullet)$ sediment, and density of tanaids in control $(\Delta)$ and defaunated $(\Delta)$ sediment. Values are means \pm 1 standard error sieved through a $1.0 \mathrm{~mm}$ mesh screen. The residue was preserved in buffered $10 \%$ seawater formalin which was dyed with rose bengal. The residue was sorted and identified under $12 \times$ magnification.

\section{Statistical analysis}

The significance of changes over time or differences between treatments was tested using SPSS programs (Nie et al., 1975). One-way analysis of variance (ANOVA) was used to test for temporal changes with the defaunation and control treatments analysed separately. Two-way ANOVA was used to test for time, defaunation, and time by defaunation interaction effects. The small-sample t-test was used to test differences between treatments at specific dates. Statistical significance was defined at $\mathrm{p}<0.5$. Infaunal abundance was transformed using the expression $y=\log _{10}$ $(x+1)$. Chlorophyll $a$, gross primary production and community $\mathrm{O}_{2}$ uptake were untransformed. In the field experiment, 3 cores from each defaunated cylinder or control plot were averaged, resulting in 2 replicates for each of the 2 treatments at each sampling date. In the laboratory experiment, each core was analysed independently, resulting in 3 replicates for each treatment at each sampling date.

\section{RESULTS}

\section{Field defaunation experiment}

Chlorophyll a in control sediment decreased significantly during the 40-d experiment, whereas chlorophyll $a$ in defaunated sediment increased significantly during this period (Fig. 1). This pattern resulted in a significant time by defaunation interaction for chlorophyll $a$ and a non-significant treatment effect when tested by the two-way ANOVA. On Day 40 , chlorophyll a concentration was 2.6 times greater in the defaunated sediment than in the controls (t-test, $0.10>p>.05$ ) Colonization of defaunated sediment by microalgae was evident as golden-brown patches where defaunated sediment had been transplanted. Neither gross primary production, nor community $\mathrm{O}_{2}$ uptake varied significantly over time or between control and defaunated sediments. Carbon equivalents of gross primary production ranged from 15 to $55 \mathrm{mg} \mathrm{C}$ $\mathrm{m}^{-2} \mathrm{~h}^{-1}$, while community $\mathrm{O}_{2}$ uptake ranged from 12 to $32 \mathrm{mg} \mathrm{C} \mathrm{m}^{-2} \mathrm{~h}^{-1}$. Total infaunal abundance in control sediment did not vary significantly over time, while animals in defaunated sediment increased $(p<.05)$ to control levels by day 40 (Fig. 1). The infaunal tanaid Leptochelia dubia (Kroyer) constituted $>63 \%$ of the 
individuals in defaunated and control sediment. Other abundant infaunal taxa were spionids, capitellids, amphipods, and the venerid bivalve Transennella tantilla (Gould). Epifaunal species were not abundant at this site.

\section{Laboratory defaunation experiment}

Chlorophyll $a$ in control sediment did not vary significantly over time (Fig. 2). Two-way ANOVA indicated significant time and defaunation effects on chlorophyll a. By Day 40, chlorophyll a was approximately 4 times greater in defaunated sediment than in control sediment (t-test, $\mathrm{p}<.05$ ). Gross primary production in control sediment did not vary significantly over $40 \mathrm{~d}$, but increased dramatically $(\mathrm{p}<.01)$ with time in defaunated sediment (Fig. 2). Two-way

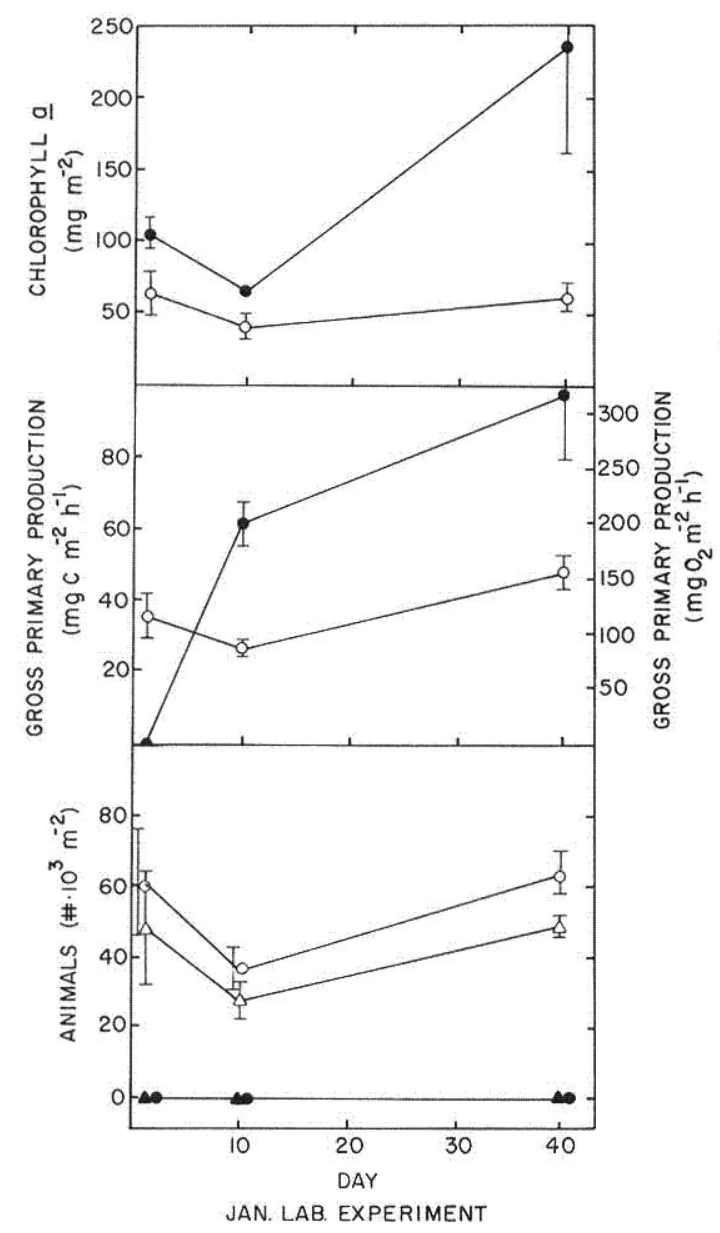

Fig. 2. Results of the laboratory defaunation experiment sampled at Days 1,10 and 40, showing concentration of chlorophyll $a$ and gross primary production in control $(0)$ and defaunated $(\bullet)$ sediment, total infaunal density in control $(0)$ and defaunated $(\bullet)$ sediment, and density of tanaids in control $(\triangle)$ and defaunated $(\Delta)$ sediment. Values are means \pm 1 standard error
ANOVA indicated significant time and time-by-defaunation interaction effects on gross primary production. Both effects resulted from gross primary production in defaunated sediments starting from zero and reaching high values by Day 10 . By Day 40 , gross primary production was approximately 2 times greater in defaunated sediment than in control sediment (t-test, $\mathrm{p}<.05$ ). Calculation of microalgal rate of growth ( $\mathrm{mg}$ $\mathrm{C} \mathrm{mg} \mathrm{chl} a^{-1} \mathrm{~h}^{-1}$ ) showed no significant differences in rate of growth between control and defaunated sediment on Days 10 and 40. The microalgal rate of growth on Day 1 was zero. Community $\mathrm{O}_{2}$ uptake in control sediment did not vary significantly over time. Community $\mathrm{O}_{2}$ uptake increased in defaunated sediment relative to control values by Day 10 , then returned to control values by Day 40. Two-way ANOVA indicated significant defaunation and time-by-defaunation interaction effects on community $\mathrm{O}_{2}$ uptake. Carbon equivalents of community $\mathrm{O}_{2}$ uptake ranged from 12 to $25 \mathrm{mg} \mathrm{C} \mathrm{m}^{-2} \mathrm{~h}^{-1}$.

Total infaunal abundance in control sediment did not vary significantly over time (Fig. 2). Average total density in the controls was $58,300 \mathrm{~m}^{-2}$ of which Leptochelia dubia constituted $>75 \%$ of the individuals. Other abundant infaunal taxa in control sediment included spionids, capitellids, and amphipods. As a result of seasonal variations, total infaunal density was about $70 \%$ greater in the January laboratory controls compared to the June field controls. Infaunal abundance in defaunated sediment was zero at Days 1 and 10 and then increased to 311 tanaids $\mathrm{m}^{-2}$ at Day 40 (Fig. 2).

There were no significant differences in chlorophyll $a_{1}$ gross primary production, community $\mathrm{O}_{2}$ uptake or total infaunal abundance between control cores maintained in the laboratory for $40 \mathrm{~d}$ and cores taken in the field on Day 39.

\section{DISCUSSION}

Placement of defaunated sediment in the field simulated localized natural disturbances such as those caused by burrowing epibenthic fishes and invertebrates or by infaunal bioturbation (Lee and Swartz, 1980). Microalgal colonization of these localized disturbances was rapid as indicated by the return of gross primary production to control levels within $10 \mathrm{~d}$. Chlorophyll $a$ also returned to control levels within 10 d. Total infaunal density returned to control levels by Day 40 , as expected from previous experiments $(\mathrm{H}$. Lee and J. Lee, unpubl.). The rapid recovery of both microalgal production and biomass indicates that this microalgal assemblage was resilient to small-scale disturbances. This resilience was probably facilitated both by 
transport of microalgae into disturbed areas (e.g. Tenore, 1977; Baillie and Welsh, 1980) and by rapid growth of colonizing microalgae (Admiraal and Peletier, 1980). As pointed out by Connell and Slatyer (1977), the size of a disturbed area influences the rate of recovery by affecting the rate of immigration of colonizers from undisturbed habitats. Thus, rapid recovery of the microalgae may not occur after largescale disturbance. Such large-scale disturbances include dredge spoil disposal and major depositional or erosional events due to storms.

We hypothesized that removal of infauna would stimulate microalgal production and biomass. This result was not readily observed in the field experiment. With the exception of the time-by-treatment interaction term for chlorophyll $a$, there was no significant enhancement of the microalgae. The possible import of microalgae into defaunated sediment during initial stages of colonization and export during later stages of colonization and initial presence of chlorophyllides in defaunated sediment would tend to minimize differences in chlorophyll $a$ and gross primary production between control and defaunated sites. Rapid recolonization by infauna also would minimize differences between treatments. Thus, the small size of the defaunated cylinders probably resulted in an underestimation of the effects of the infauna.

To better evaluate influences of the infauna on the microalgae, a laboratory experiment was performed which reduced the confounding effects of importexport of microalgae and infaunal colonization. By reducing microalgal and infaunal recolonization rates, the laboratory experiment simulated a large scale disturbance. Similarity of levels of chlorophyll a, gross primary production, community $\mathrm{O}_{2}$ uptake and infaunal abundance between control cores held in the laboratory for $40 \mathrm{~d}$ and the natural field community indicated that maintenance of cores did not strongly affect community structure or function. Therefore, the laboratory experiment was an appropriate method to determine effects of infauna on sediment-associated microalgae.

In the laboratory, removal of infauna caused a significant increase in microalgal biomass and production. The relatively high concentration of chlorophyll a in defaunated sediment on Day 1 was not functional as indicated by the lack of gross primary production. Growth of microalgae in the defaunated sediment was shown by increased gross primary production by Day 10 , although chlorophyll a remained constant. By Day 40 , chlorophyll a concentration was about 4 -fold greater and gross primary production about 2 -fold greater in the defaunated sediment than the controls. These results indicate that natural densities of infauna can control both microalgal biomass and production, as has been found for several estuarine epifaunal gastropods (Fenchel and Kofoed, 1976; Pace et al., 1979; Branch and Branch, 1980). Natural infaunal density at the study site exceeded the level at which microalgal and microbial rates of growth are stimulated by consumption of senescent cells or nutrient additions (Hargrave, 1970, 1976; Cooper, 1973; Porter, 1976; Pace et al., 1979).

Grazing is the most likely mechanism by which infauna controlled microalgal biomass and production. The most abundant species at the study site, Leptochelia dubia, contained both broken and whole diatom frustules in its gut indicating herbivory as was suggested for another tanaid, Leptochelia rapax (Harger) (Kneib et al., 1980). Burial of cells by sediment turnover is another mechanism by which infauna could limit microalgae. However, Leptochelia does not appear to turn over large quantities of sediment (Myers, 1977) and active sediment reworkers such as Callianassa were not abundant in our study site. The process of defaunating sediment may have increased nutrient concentrations which in turn could have stimulated microalgal growth. However, laboratory and field experiments at the study site showed that sediment-associated microalgae did not respond to nutrient additions indicating that they were not nutrient limited (Cardon, 1981).

Patterns of community $\mathrm{O}_{2}$ uptake were difficult to interpret. In the field, community $\mathrm{O}_{2}$ uptake of defaunated sediment recovered to control values between Days 10 and 40 . In the laboratory, community $\mathrm{O}_{2}$ uptake of defaunated sediment was initially identical to control sediment, increased to greater than control levels between Days 1 and 10 and then decreased to control values between Days 10 and 40. Causes for the different patterns in the field and laboratory experiments are not apparent. The low macrofaunal density ( 0 to $311 \mathrm{~m}^{-2}$ ) and diversity ( 0 to 1 species) in the defaunated sediment in the laboratory normally would constitute strong evidence for a highly degraded benthic community, yet community $\mathrm{O}_{2}$ uptake at Day 40 was the same in control and defaunated sediment. This similarity of community metabolism between these radically different benthic communities indicates that there is no simple relationship between community $\mathrm{O}_{2}$ uptake and infaunal community structure.

Pace et al. (1979) suggested that herbivory is one of the factors regulating microalgal biomass and production although its relative importance, compared to other factors, is unknown. The experimental evidence presented here indicates that natural densities of infauna can regulate sediment-associated microalgae. Differences in infaunal abundance and activity may be one of the factors influencing both spatial and tem- 
poral patterns of microalgae. The influence of animals on plant communities is a widespread phenomenon and should not be ignored when assessing factors controlling plant growth (Brook, 1975).

Acknowledgements. This work was partially supported by grants from the US Environmental Protection Agency \# R806780 to C. D. McIntire. H. Lee was supported during a portion of this research by a National Research Council Fellowship with the Environmental Protection Agency. We are grateful to D. J. Specht, R. C. Swartz, and G. E. Walsh for criticizing the manuscript.

\section{LITERATURE CITED}

Admiraal, W. (1977). Experiments with mixed populations of benthic estuarine diatoms in laboratory microecosystems. Botanica mar. 20: 479-485

Admiraal, W., Peletier, H. (1980). Influence of seasonal variations of temperature and light on the growth rate of cultures and natural populations of intertidal diatoms. Mar. Ecol. Prog. Ser. 2: 35-43

Amspoker, M. C., McIntire, C. D. (1978). Distribution of intertidal diatoms associated with the sediments in Yaquina estuary, Oregon. J. Phycol. 14: 367-395

Baillie, P. W., Welch, B. L. (1980). The effect of tidal resuspension on the distribution of intertidal epipelic algae in an estuary. Estuar. coast. mar. Sci. 10: 165-180

Branch, G. M., Branch, M. L. (1980). Competition in Bembicium auratum (Gastropoda) and its effect on microalgal standing stock in mangrove mudflats. Oceologia (Berl.). 46: $106-114$

Brook, A. J. (1975). Aquatic animals aren't hungry in winter, or why Cymbella blooms beneath the ice. J. Phycol. 11: 235

Cadée, G. C., Hegeman, J. (1974). Primary production of the benthic microflora living on tidal flats in the Dutch Wadden Sea. Neth. J. Sea Res. 8: 260-291

Cardon, N. C. (1981). The effect of nutrient enrichment on benthic diatoms of Yaquina Bay, Oregon, M. S. thesis, Oregon State University, Corvallis

Connell, J. H., Slatyer, R. O. (1977). Mechanisms of succession in natural communities and their role in community stability and organization. Am. Nat. 111: 1119-1144

Cooper, D. C. (1973). Enhancement of net primary productivity by herbivore grazing in aquatic laboratory microcosms. Limnol. Oceanogr. 18: 31-37

Coles, S. M. (1979). Benthic microalgal population on intertidal sediments and their role as precursors to salt marsh development. In: Jeffries, R. L., Davy, A. J. (eds.) Ecological processes in coastal environments. Blackwell, Oxford, p. $25-42$

Davis, M. W. (1981). Production dynamics of sediment-associated algae in two Oregon estuaries, Ph. D. thesis, Oregon State University, Corvallis

Fenchel, T. (1969). The ecology of marine microbenthos IV. Structure and function of the benthic ecosystem, its chemical and physical factors and the microfaunal communities with special reference to the ciliated protozoa. Ophelia 6: $1-187$

Fenchel, T., Kofoed, L. H. (1976). Evidence for exploitative interspecific competition in mudsnails (Hydrobidae). Oikos 27: $367-376$
Hargrave, B. T. (1970). The effect of a deposit-feeding amphipod on the metabolism of benthic microflora. Limnol. Oceanogr. 15: 21-30

Hargrave, B. T. (1976). The central role of invertebrate feces in sediment decomposition. In: Anderson, J. M., Macfadyen, A. (eds.) The role of terrestrial and aquatic organisms in decomposition processes. Blackwell, Oxford, p. 301-321

Kneib, R. J., Stiven, A. E., Haines, E. B. (1980). Stable carbon isotope ratios in Fundulus heteroclitus (L.) muscle tissue and gut contents from a North Carolina Spartina marsh. J. exp. mar. Biol. Ecol. 46: 89-98

Lee, H. II, Swartz, R. C., (1980). Biological processes affecting the distribution of pollutants in marine sediments, Part II. Biodeposition and bioturbation. In: Baker, R. A. (eds.) Contaminants and sediments, Vol. 2. Ann Arbor Sci. Publ., Inc. p. 555-606

Levinton, L. S. (1980). Particle feeding by deposit-feeders: models, data and a prospectus. In: Tenore, K. R., Coull, B. C. (eds.) Marine benthic dynamics. University of South Carolina Press, Columbia, p. 423-439

Montgomery, J. R., Zimmermann, C. F., Price, M. T. (1979). The collection, analysis, and variation of nutrients in estuarine pore water. Estuar. coast. mar. Sci. 9: 203-214

Myers, A. C. (1977). Sediment processing in a marine subtidal sandy bottom community: I. Physical aspects. J. mar. Res. 35: 609-632

Nie, N. H., Hill, C. H, Jenkins, J. S., Steinbrenner, K., Bent, D. H. (1975). SPSS: statistical package for the social sciences, 2nd ed. McGraw-Hill, New York

Pace, M. I., Shimmel, S., Darley, W. M. (1979). The effect of grazing by a gastropod, Nassarius obsoletus, on the benthic microbial community of a salt marsh mudflat. Estuar. coast. mar. Sci. 9: 121-134

Pomeroy, L. R. (1959). Algal productivity in salt marshes of Georgia. Limnol. Oceanogr. 4: 386-397

Porter, K. G. (1976). Enhancement of algal growth and productivity by grazing zooplankton. Science, N. Y. 192: 1332-1334

Sanders, H. L., Goudsmit, E. M., Mills, E. L., Hampson, G. E. (1962). A study of the intertidal fauna of Barnstable Harbor, Massachusetts. Limnol. Oceanogr. 7: 63-79

Strickland, J. D. H., Parsons, T. R. (1972). A practical handbook of seawater analysis, 2nd ed. Bull. Fish. Res. Bd Can. 187: $1-310$

Tenore, K. R. (1977). Foodchain pathways in detrital feeding benthic communities: a review with new observations on sediment resuspension and detrital recycling. In: Coull, B. C. (ed.) Ecology of marine benthos. University of South Carolina Press, Columbia, p. 37-53

Welsh, B. L. (1980). Comparative nutrient dynamics of a marsh-mudflat ecosystem. Estuar. coast. mar. Sci. 10: 143-184

Westlake, D. F. (1965). Some basic data for investigations of the productivity of aquatic macrophytes. Memorie Ist. ital. Idrobiol. 18: 229-248

White, D. D., Findlay, R. H., Fazio, S. D., Bobbie, R. J., Nickels, J. S., Davis, W. M., Smith, G. A., Martz, R. F. (1980). Effects of bioturbation and predation by Mellita quinquiesperforata on sedimentary microbial community structure. In: Kennedy, V. S. (ed.) Estuarine perspectives. Academic Press, New York, p. 163-171

Whitney, D. E., Darley, W. M. (1979). A method for the determination of chlorophyll $a$ in samples containing degradation products. Limnol. Oceanogr. 24: 183-186 